\title{
PEDAGOGICAL CONDITIONS OF DEVELOPMENT OF PROFESSIONAL POTENTIAL OF FUTURE FOREIGN LANGUAGE TEACHERS IN THE PROCESS OF THEIR PROFESSIONAL TRAINING
}

\author{
Katalin Hnatyk ${ }^{1}$ \\ ${ }^{I}$ English teacher of Philology Department, Transcarpathian Hungarian Institute after Ferenc Rákóczi II, \\ Berehove, Ukraine, e-mail: mesterkati29@gmail.com, ORCID: http://orcid.org/0000-0003-4975-6266
}

\begin{abstract}
The article under consideration gives scientific grounding of pedagogical conditions for the development of professional potential of future foreign language teachers in the process of their professional training. It has been assumed that the pedagogical conditions for the development of professional potential of future foreign language teachers in professional training should reflect: qualitative characteristics of basic factors, processes and phenomena of educational environment, reflecting the basic requirements for professional training of future foreign language teachers in higher educational establishment; complex of objective opportunities, which have been purposefully made up and implemented into educational environment, provide solutions to given pedagogical tasks; a set of the following measures increase the efficiency of the process of development of professional potential of future foreign language teachers: information (content of education; cognitive basis of pedagogical process); technological (forms, means, methods, approaches, levels, ways of organization of educational activity; procedural, methodical basis of academic process); personal (behavior, activity, communication, personal qualities of subjects of educational process); psychological (organization of reflective activity, etc.). Taking into consideration the peculiarities of professional activity of future foreign language teachers, the following factors have been singled out as pedagogical conditions that ensure the highest efficiency of development of all components of professional potential of students of investigated specialty: formation of positive "I-conception" of a professional in students' ideology; ensuring the formation of professional outlook of future foreign language teachers by means of expanding the content of academic disciplines with information of interdisciplinary character; use of educational context of professional training of future foreign language teachers as the basis for the development of professional potential; organization of reflective and creative educational activities of students.
\end{abstract}

Keywords: potential, professional potential, future teachers of foreign language, students, conditions, pedagogical conditions, methods.

JEL Classification: JEL I0; I20

Formulas: 0; fig.: 0, tabl.: 0; bibl.: 12

Introduction. One of the primary tasks which are set for higher educational establishments by the State National Program "Education" (Ukraine of the XXI century) is a thorough and high-quality professional training of specialists, in particular, future teachers of philology. Nowadays, the state program "Teacher," National Doctrine of Education, Conceptual framework of development of pedagogical education in Ukraine and its integration into European educational environment specify basic demands to professional training of modern teacher as the subject of personal-oriented and professional development who permanently broadens and updates subject areas of own professional activity. Thus, the changes which have been actively implemented over the last decade in teaching methods indicate that today the general teaching community is beginning to realize the essence and specifics of the new philosophy of education, which determines the orientation of learning process into personalities development of students[3]. 
The process of further renewal of the higher education system are objectively aimed primarily at meeting the needs of society and the state in qualified teachers, which presupposes appropriate changes in professional training, development and self-development of future foreign language teachers in the direction of professional potential. Such changes involve the introduction of effective pedagogical factors which contribute to the development of the outlined phenomenon.

Literature Review. The study of the problem of development of pedagogical conditions of professional potential of future foreign language teachers in the process of professional training involves a thorough analysis of the concept of "pedagogical conditions". In the information and reference literature $[3 ; 7 ; 5]$ the definition of the notion "condition" is interpreted as a category of philosophy that determines the attitude of the subject to the surrounding phenomena, without which its existence is impossible [8, p. 7]; the set of circumstances the origin depends on, existence and development of objects or phenomena [12, p. 84]. Whereas in the psychological and pedagogical literature the concept of "pedagogical conditions" is defined as a set of circumstances or opportunities which determines the functioning and dynamics of a particular pedagogical system (O. Homonyuk [5, p. 68]); factors of development of pedagogical system and efficiency of pedagogical process $(\mathrm{N}$. Dobizha [117, p. 245]); the result of selection and successful organization of techniques, methods and forms of study to achieve a certain goal (V. Kalinin [9, p. 23]); circumstances of the educational process that ensure its effectiveness (I. Kostikova [10, p. 109]); external circumstances and factors of effective influence on the pedagogical process, constructed by the teacher in improving this process (I. Mazaykina [11, p. 9]). A common feature for all these definitions is the interpretation of pedagogical conditions as factors of positive influence on the course of pedagogical processes or on the functioning of pedagogical systems for increasement of their effectiveness.

Hence, on the basis of analysis of the outlined positions concerning the definition of the term "pedagogical conditions», it has been singled out a wide range of issues, that are significant for the present dissertation thesis:

1) pedagogical conditions are considered to be an essential element of integrated educational process;

2) pedagogical conditions reflect a set of opportunities of the educational environment (measures of interaction of educational subjects are purposefully constructed: content, forms, methods and techniques of teaching, software and methodological support of the educational process) and material and spatial environment (training labs, technical equipment, etc.) which provide functioning of professional training of students;

3 ) in the structure of pedagogical conditions it is possible to single out internal and external elements. Internal elements support the development of the personality sphere of subjects of educational process. External elements provide the formation of process component of pedagogical system;

4) realization of particular pedagogical conditions provides the effectiveness of functioning of professional training of future foreign language teachers. 
Aims. The article aims at theoretical substation of pedagogical conditions of development of professional potential of future foreign language teachers in the process of their professional training.

Methods. The following research methods have been used in realization of the set objective: theoretical (analysis of pedagogical, educational and methodical, normative literature and scientific works on the topic of the current article, subject, logical and information-target analysis of text materials; empirical: expert survey.

Theoretical and comparative analysis of scientific literature showed, that pedagogical conditions of the development of professional potential of future foreign language teachers in the process of their professional training have not become the topic of scientific investigation of the researchers. From this respect, the method of expert evaluation of the efficiency of pedagogical conditions has been applied. Thus, the teachers of higher educational establishment, participating in the experiment research, have been suggested to be the experts. In the context of the carried out survey, the experts have been asked to determine the most effective, in their opinion, pedagogical conditions for the development of professional potential of future foreign language teachers in the process of their professional training. This survey made it possible to rank and determine those pedagogical conditions which should be implemented in the process of study in a higher educational establishment in order to form the studied phenomenon in future teachers of this specialty.

Results. The generalization of results of a wide range of scientific and pedagogical studies proves that in pedagogical theory and practice there are several types of pedagogical conditions, namely: organizational and pedagogical $(\mathrm{N}$. Andrushchenko [1]), psychological and pedagogical (O. Antonenko [3]), psychological didactic (N. Dobizha [6]) didactic conditions (O. Malykhin [12]), etc.

Summing up the information mentioned above, it can be assumed, that pedagogical conditions of development of professional potential of future foreign language teachers in their professional training must reflect:

- qualitative characteristics of the basic factors, processes and phenomena of the educational environment, reflecting the key requirements towards the organization of professional training of future teachers of foreign language in higher educational establishment;

- the unity of objective opportunities, circumstances of teaching process, created purposefully and implemented in the educational environment, which provide the fulfillment of pedagogical tasks and the achievement of the goal of the research;

- a set of measures which increase the efficiency of the process of development of professional potential of future foreign language teachers: information (content of education; cognitive basis of pedagogical process); technological (forms, means, methods, approaches, stages, ways of the organization of educational activity; procedural and methodical basis of pedagogical process); personality (behavior, activity, communication, personal features of subjects of educational process); psychological (organization of reflective activities, etc.).

Discussion. Based on the works of researchers towards interpretation of the terms "condition", "pedagogical conditions" and based on the laws of pedagogical 
process and fundamentals of didactics, under the pedagogical conditions of development of professional potential of future foreign language teachers in the process of professional training we consider the complex of interrelated factors of educational environment of a higher educational establishment (objective possibilities of the essence of study, organizational forms and material possibilities of their implementation), the construction of which is based upon the introduction of author's educational and methodical materials into the process of educational and cognitive activity of students, ensuring successful achievement of the aim of the research.

Taking into consideration peculiarities of professional activity of future teachers of foreign language and appealing to the existing principles of organization of educational process in higher educational establishments, the following selected factors ensure the highest efficiency of development of essential components for professional potential of by pedagogical conditions:

1) formation of the positive «I-image» of a professional in the student's outlook by means of «case» method implementation;

2) ensuring the formation of professional worldview of future foreign language teachers on the basis of expanding the content of academic disciplines with information of an interdisciplinary character;

3) implementation of educational context of professional training of future foreign language teachers as the basis for the development of professional potential;

4) organization of reflective and creative educational activity of students.

The factors mentioned above can be explained in the following way.

In its traditional understanding «case» method or «case» study (from English «case»- situation) - it is an active method of study based on a group analysis of the situation (case) and finding effective ideas for its solution, taking into consideration specific conditions [7]. English term «case study» must not be translated precisely into Ukrainian [8]. From this respect, the following synonyms are provided in scientific literature: case-study, case-method, method of cases, study upon practical examples, method of concrete situations, situational study.

It has been assumed that in the process of completing the author's cases, students form the outlined components of the professional consciousness of future foreign language teachers. From this respect, in the process of professional training of future foreign language teachers various types of cases were implemented, namely:

- cases which are directed to the formation of professional health of future teachers of foreign language;

- cases which support the development of moral and conceptual positions of future teachers of foreign language;

- cases which contribute the professional ideal in student's outlook;

- cases which determine the development of professional valuable orientations;

- cases with the content that presupposes actualization and development of professional identity of future teachers of foreign language.

Such palette of authorial and modified cases helped to unite the diversity of students' ideas about themselves as professionals in the consciousness of future 
foreign language teachers; their professional roles, the level of development of professional qualities; as well as professional functions of a teacher; norms, rules, models of behavior in the context of professional actions as standards for "Iunderstanding" as the example of the perfect teacher of foreign language etc.

The broadening of traditional process of professional training of future foreign language teacher by the author's situational tasks intended to contribute to the formation of a common value and content field of professional training of students. At the same time, such investigating decision required some modification of the content of selected courses. Therefore, the second pedagogical condition has been singled out as providing the formation of professional worldview of future foreign language teachers on the basis of expanding the content of academic disciplines with information of interdisciplinary character, which had presupposed the formation of cognitive-worldview component of professional potential of students in the process of their professional training.

In current scientific discourse the notion «outlook» found its theoretical grounding in works of I. Kocstikova [10]. Thus, summing up the positions, which have been formed by I. Lerner, B. Lykhachov, the scientist determines outlook as a set of views, assessments, principles that determine the most common understanding of the world [10, p. 271]. In his turn, S. Its [8] proves the idea about ideology as an integrated understanding about the world and the place of a human-being in it, a system of extremely generalized views about nature and society; philosophic, sociopolitical, moral, scientific orientation of an individual or social group; basic life positions, system of beliefs, ideas of outlook [8, c. 24].

Within implementation of the second pedagogical condition we will appeal to the scientific position of the author, according to which the development of professional worldview of future teachers is based on the established system of general and special professional knowledge. Therefore, we believe that professional worldview of future foreign language teachers will become the result of generalization of theoretical, scientific, methodological worldview of the essence of the future profession by students.

Among the indicators of establishment of professional ideology of future foreign language teachers the following can be distinguished:

- synthetics of professional knowledge, the central element of which is a fluent command of a foreign language;

- professional, value-semantic dispositions of a teacher, which are reflected in the strategy of teaching activity and influence the understanding and perception of the phenomena of socio-cultural reality within the native and foreign linguistic communities;

- formation of teaching conceptual thinking;

- ability to estimate the reality, its critical thinking in pedagogical categories and expression in the form of a "thought";

- manifestation of professional pedagogical identity by students;

- the established attitude onto professional perception of multicultural reality. 
Implementation of training exercises which have been worked out involved not only including of interdisciplinary information into the content of selected disciplines, but was also based on the actualization of the context of professional training of future foreign language teachers. Therefore, the third pedagogical condition of the study is distinguished as the use of educational context of professional training of future foreign language teachers as the basis for the development of professional potential.

This pedagogical condition has been implemented on the basis of works of A. Verbytskyi, concerning the organization of contextual study of students in higher educational establishments. After all, as N. Dobizha summarizes [6], in terms of using the context of professional training of future foreign language teahers students' activity is directed not on expansion of knowledge, abilities, skills, but on the solution of the offered professional, problem - oriented tasks [6, c. 249].

It has been taken into account that the basic characteristic of educational environment based on the principles of contextual education, which is implemented through a system of new and traditional forms and methods of teaching, as states I. Mazaikina [141], is active modeling of subjective and social content of future professional activity within the use of language semiotics (including foreign).

The concept of contextual study has a wide range of advantages that form the basis for organization of professional and educational activity of students. At the same time, implementation of the third pedagogical condition appealed to the necessity of development of communicative skills of future foreign language teachers, in particular:

a) language communication (perfect command of modern professional terminology; ability to make up the monologue on any professional topic etc);

б) adequate perception and interpretation of cognitive and emotional information;

c) provide the atmosphere of mutual understanding, interrelation and interaction in lessons of foreign language (taking into account the peculiarity of the communicative situation with different age groups of pupils; forseeing the impact of teacher's acts or language on the behavior of pupils), etc. Appealing to the scientific position of V. Bezlyudna [4], for the effective use of the context of professional training of future foregn language teachers interactive methods of organizion of educational activities of students are used, which involved the construction of situational and problem tasks.

The fourth pedagogical condition in its turn - organization of reflexive, creative educational activity of students - has been directed onto the development of the fourth component of professional potential of future foreign language teachers. Analysis of academic curricula of basic educational programes under which the professional training of future foreign language teachers in higher educational establishment of Ukraine is realized, has testified that individual work of students prevails over the classsroom work. Therefore, responsibility for academic results of both (a student and a teacher) increases. From this very reason future foreign language teachers must have a conscious ability to reflect. 
In this context, implementation of the fourth factor intended the construction of special didactic units (problem tasks, research projects, etc.) to ensure the development of creative individual and professional qualities of future foreign language teachers. The student's reflection is in this case the indicator of subjectivity and allows the individual to regulate their own activity, to influence upon the system of norms and standards of professional pedagogical activity of teachers of foreign language, to manage their own educational and practical activities.

It has been prognosed, that taking reflective position, a student analyses, gives critical thinking to its activity by means of given, proposed, made up, problematic tasks comparing objectives with results. Thus, reflection is understood as the ability of future teachers of foreign language to be aware of their own educational and professional activities in terms of achieving the intended pedagogical goals. In this case, the reflection focuses on finding the causes of failures and difficulties, in the process of which students realize that the means they used to complete the task did not achieve the overall goal. As a result, a critical attitude to one's own inner personal and professional psychophysical abilities is being formed.

Conclusions. In order to develop potential abilities and to enrich professional knowledge, skills, personal qualities during the period of professional training in higher educational establishment certain pedagogical factors should be realized: formation of a positive "I-image" of a professional in students' ideology using "case" method; ensuring the formation of professional outlook of future foreign language teachers on the basis of expanding the content of academic disciplines within information of interdisciplinary character; implementation of educational context of professional training of future foreign language teachers as the appropriate basis for the development of professional potential; organization of reflective and creative educational activities of students.

Hence, implementation of pedagogical conditions for development professional potential of future foreign language teachers as the complex of organizational and methodical measures, will provide achievement of research aim and provides a harmonious combination of traditional and innovative forms, methods, means of the organization of educational activity of students.

The present study does not cover all aspects of the problem of development of future foreign language teachers in the process of professional training. The prospects of further investigations are supposed to be in the improvement of the content of the development of professional potential of students of philological specialties on the basis of praxeological approach and by means of modern information technologies in the process of professional training of future foreign language teachers.

\section{References:}

1. Andrushchenko N. O. Vykorystannya interaktyvnykh metodiv navchannya u zakladakh vyshchoyi osvity. Interaktyvnyy osvitniy prostir ZVO [The use of interactive teaching methods in higher education. Interactive educational space of higher educational establishment]: materialy mizhvuzivskoho naukovo-praktychnoho vebinaru (m. Vinnytsya, 23 bereznya 2018 r.). Vinnytsya : VTEI KNTEU, 2018. S. 7-10.

2. Andyusev B. E. Keys - metod kak ynstrument formyrovanyya kompetentnostey [Case - a method as a tool for the formation of competencies]. Dyrektor shkoly. 2010. № 4. S. 61-69.

3. Antonenko O. V. Profesiyna pidhotovka vchyteliv inozemnykh mov v konteksti modernizatsiyi vyshchoyi osvity v Cheskiy respublitsi. Problemy ta perspektyvy formuvanya natsionalnoyi humanitarno- 
tekhnichnoyi elity [Professional training of foreign language teachers in the context of modernization of higher education in the Czech Republic] : zb. nauk. pr. / red. L. L. Tovazhnyanskyy, O. H. Romanovskyy.Kharkiv: NTU «KHPI», 2015. Vyp. 43 (47). S. 70-76.

4. Bezlyudna V. V. Zmina kharakteru profesiynoyi pidhotovky maybutnikh uchyteliv inozemnykh mov u konteksti vymoh Bolonskoho protsesu [Changing the nature of professional training of future foreign language teachers in the context of the requirements of the Bologna process]. Molod i rynok: shchomisyachnyy nauk. 2017. № 4 (147). S.103-108.

5. Homonyuk O. M. Osobystisnyy aspekt diyalnosti maybutnoho pedahoha - sposib yoho samorozvytku ta samorealizatsiyi [Personal aspect of the future teacher - a way of his self-development and self-realization]. Zbirnyk naukovykh prats Natsionalnoyi akademiyi Derzhavnoyi prykordonnoyi sluzhby Ukrayiny imeni B. Khmelnytskoho. Seriya pedahohichni nauky / za red. O. V. Didenko. Khmelnytskyy: NADPSU, 2016. №4(6). S. 66 -74.

6. Dobizha N. V. Rol samovyznachennya u formuvanni indyvidualnoho stylyu pedahohichnoho spilkuvannya maybutnoho vchytelya inozemnoyi movy $\mathrm{v}$ protsesi pedahohichnoyi praktyky [The role of self-determination in the formation of individual style of pedagogical communication of the future teacher of a foreign language in the process of pedagogical practice]. Naukovyy visnyk Pivdennoukrayinskoho natsionalnoho pedahohichnoho universytetu im. K. D. Ushynskoho. 2011. №5/6. S. $244-254$.

7. Dolhorukov A. M. Metod case-study kak sovremennaya tekhnolohyya professyonalno-oryentyrovannoho obuchenyya [Case-study method as a modern technology of vocational training]. URL: http://www.evolkov.net/case/case.study.html. (data zvernennya: 21.06.2019)

8. Its S. V. Pedahohichni umovy formuvannya profesiynoyi kompetentnosti maybutnoho vchytelya inozemnoyi movy zasobamy mediaosvity [Pedagogical conditions of formation of professional competence of the future teacher of a foreign language by means of media education]: avtoref. dys. ... kand. ped. nauk: 13.00.04. Zhytomyr, 2014. $22 \mathrm{~s}$.

9. Kalinin V. O. Tekhnolohiyi formuvannya profesiynoyi sotsiokulturnoyi kompetentsiyi maybutnoho vchytelya inozemnoyi movy [Technologies for the formation of professional socio-cultural competence of the future teacher of a foreign language]: navch.-metod. posib. Zhytomyr: «Polissya», 2008. $104 \mathrm{~s}$.

10. Kostikova I. Teoretyko-metodychni zasady profesiynoyi pidhotovky maybutnikh uchyteliv inozemnykh mov zasobamy informatsiyno-komunikatsiynykh tekhnolohiy [Theoretical and methodological principles of professional training of future teachers of foreign languages by means of information and communication technologies]: dys. ... d-ra ped. nauk: 13.00.04. Kharkiv, 2009. 469 s.

11. Mazaykina I. O. Formuvannya hotovnosti maybutnikh uchyteliv do zastosuvannya osobystisno oriyentovanykh pedahohichnykh tekhnolohiy navchannya inozemnykh mov u profesiyniy diyalnosti [Formation of readiness of future teachers for application of personally oriented pedagogical technologies of teaching foreign languages in professional activity]: avtoref. dys. ... kand. ped. nauk : 13.00.04. Vinnytsya, 2018. $23 \mathrm{~s}$.

12. Malykhin O. V., Hrytsenko I. S. Teoretychni osnovy realizatsiyi kompetentnisnoho pidkhodu v orhanizatsiyi samostiynoyi osvitnoyi diyalnosti studentiv filolohichnykh spetsialnostey : monohrafiya. Kyyiv [Theoretical bases of realization of the competence approach in the organization of independent educational activity of students of philological specialties: monograph] : NUBiP Ukrayiny, 2016. $489 \mathrm{~s}$.

Received: January 05, 2021 Approved: February 01, 2021 